\title{
Cattle grazing white locoweed in New Mexico: Influence of grazing pressure and phenological growth stage
}

\author{
MICHAEL H. RALPHS, DAVID GRAHAM AND LYNN F. JAMES
}

\section{Range Scientist and Research Leader, respectively, USDA/ARS Poisonous Plant Lab, Logan UT 8432I; Union County Extension Agent, Clayton NM 88415.}

Abstract

Locoweed poisoning generally occurs in early spring when other forage is dormant or in short supply and locoweed is the main green plant available to grazing livestock. The objective of this study was to estimate the amount of white locoweed (Oxytropis Sericea Nut. ex T\&G) consumed by cattle, and to determine if cattle graze locoweed because it is relatively palatable, or if they are forced to graze it because of decreasing availability of other forage. Three grazing trials were conducted that corresponded to the vegetative, flower, and pod phenological growth stages of white locoweed. Four cows were used in Trial 1 (vegetative growth stage), and 7 cows were used in Trials 2 (flower stage) and 3 (pod stage). Pastures were fenced for the 10day grazing trials, so that forage became limited and grazing pressure increased as the trials progressed. Acceptance of white locoweed at the beginning of each trial, when there was adequate forage, would indicate preference. Rejection of white locoweed at the beginning of the trials, followed by increasing consumption as the trials progressed would indicate that grazing pressure was forcing the cows to select white locoweed. White locoweed was readily accepted by 1 cow in the vegetative trial, and by 2 cows in the flower trial (these cows were termed "loco-eaters"). The remainder of the cows (termed "normal") rejected white locoweed in the vegetative and flower trials until the availability of new growth cool-season grasses decreased, after which they started to select white locoweed. All cows rejected white locoweed at the beginning of the pod trial, but consumed it as availability of other plants decreased. Regression analysis showed that grazing pressure was positively associated with ingestion of white locoweed $\left(r^{2}=.46\right.$ to .88$)$ by the "normal" cows.

Key Words: grazing pressure, cattle grazing, poisonous plants, white locoweed, Oxytropis serica.

Locoweed poisoning was often confused with starvation in early reports (Marsh 1909). The clinical signs of locoweed poisoning (depression, rough hair coat, emaciation) are similar to those of starvation. Furthermore, locoweed poisoning generally occurred in the late winter or early spring (Marsh 1909, Peters and Sturdevent 1908, James et al. 1968, 1969, Patterson 1982) when forage was typically in short supply.

Many locoweed species in the southwestern U.S. are biennials or

\footnotetext{
The authors thank Justin Williams for collecting the data, Hennigan Ranches for care and Clayton Livestock Research Center, New Mexico State University for use of facilities and equipment.

Manuscript accepted 15 Nov. 1994.
}

short-lived perennials that germinate and grow in the fall following late summer and autumn rains (Welsh 1989). They remain green during mild winters, or are the first plants to green up and resume growth in the spring, and they are often the only green plants available among dry, dormant grasses during this period. Ralphs et al. (1993) reported that cattle consumed moderate amounts of white locoweed (Oxytropis sericea Nut. ex T\&G) throughout the spring, but ceased grazing it when warm-season grasses started rapid growth in June. The objective of the present study was to determine if cattle graze white locoweed because it is relatively palatable, or if they are forced to graze it because of increasing grazing pressure resulting from diminishing forage availability. We hypothesized that white locoweed was not innately palatable and that cattle would not select it if other forage was abundant. We anticipated that cattle would begin to graze locoweed as the forage supply decreased inc grazing pressure on the remaining forage increased. Grazing trials were conducted during the vegetative, flower, and pod phenological growth stages of white locoweed, to evaluate the relative palatability of white locoweed at each stage with respect to increasing grazing pressure.

\section{Methods}

The study was conducted in eastem Colfax County, $32 \mathrm{~km}$ east of Raton in northeastern New Mexico. The site was a northeast exposure, $10 \%$ slope, at $2,200 \mathrm{~m}$ elevation. Soils were silty clay loam with round volcanic rocks scattered in various densities throughout the site. This appears to be the preferred habitat of white locoweed in this region. Cool-season grasses included: western wheatgrass (Pascopyrum smithii (Rybd.) A. Love), squirreltail (Elymus elymoides (Raf.) Swezey) and sedge (Carex spp.). Warm-season grasses included: blue grama (Bouteloua gracilis (H.B.K.) Lag. ex Steudel), sideoats grama (B. curtipendula (Michx.) Torr.), little bluestem (Schizachyrium scoparium (Michx.) Nash), and 3-awns (Aristida spp.). White locoweed dominated the forb component. 10-day grazing trials were conducted during the vegetative, flower, and pod phenological growth stages of white locoweed.

\section{Trial 1, Vegetative Stage, April 16 to 25}

White locoweed was actively growing with leaves 8 to $15 \mathrm{~cm}$ long. Cool- season grasses were green and actively growing with leaves 8$10 \mathrm{~cm}$ long. Warm-season grasses were dormant.

\section{Trial 2, Flower Stage, May 5 to 14}

White locoweed leaves were $12-20 \mathrm{~cm}$ long and flower stalks were $30 \mathrm{~cm}$ tall and flowering. Cool-season grasses were 15 to $20 \mathrm{~cm}$ tall 
and growing rapidly. Warm-season grasses were green but had not started rapid growth.

\section{Trial 3, Pod Stage, June 15 to 24}

Locoweed pods were immature to fully expanded and were still succulent. Cool-season grasses were headed out and warm-season grasses were growing rapidly. Forbs were abundant and flowering.

Pasture differences were confounded with growth stages in this study. Separate pastures were constructed for each of the 3 trials, and were located side-by-side on the same hill slope in an attempt to minimize differences between pastures. Because pastures were not replicated, results from this study cannot be extrapolated beyond the conditions of this study.

Standing crop was estimated at the beginning and end of each trial. Ten, .25-x 1-m quadrats were systematically placed along each of 2 paced transects bisecting the length of each pasture. Species were clipped at ground level and grouped into the following forage classes: cool-season grasses, warm-season grasses, forbs, locoweed leaves, and locoweed heads. Samples were dried in a forced-air oven at $60 \mathrm{C}$ for 48 hour and weighed.

Standing crop at the beginning of each trial was used to calculate pasture size. The amount of feed required to sustain the cows for 10 days was determined from NRC nutrient requirements ( 9 $\mathrm{kgDM} / \mathrm{cow} / \mathrm{day}$ ). Half the grass standing crop was considered available for consumption. The size of the pasture required to provide that amount of feed was calculated and fenced with temporary electric fence. Standing crop, pasture size, and grazing pressure are shown in Table 1. Even though grass standing crop was less in Trial 3 than in Trial 2, the pasture size in Trial 3 was kept at 1.7 ha in anticipation of rapid forage growth during this trial.

Eight Hereford and Angus cows $(380 \pm 105 \mathrm{~kg}$ ) were retained from a previous locoweed grazing study (Ralphs et al. 1993). Locoweed consumption by these cows in the previous trial varied from a high of $30 \%$ of their diets to a low of $5 \%$. However, 4 of the cows died from residual locoweed toxicity in March before the first trial began; hence Trial 1 (vegetative stage) was conducted with only 4 cows. Three additional cows with histories of eating locoweed were purchased and included in Trial 2 (flower stage) and Trial 3 (pod stage).

All cows had grazed on white locoweed infested ranges and were familiar with the vegetation community. Between trials, the cows were kept in a nearby locoweed-free pasture with vegetation similar to the study pasture. They were denied access to white locoweed between the trials to prevent those that were eating it from becoming severely poisoned and incapable of completing the trials. The cows were supplemented with $0.9 \mathrm{~kg} / \mathrm{cow}$ of cotton seed cake (protein supplement) every other day throughout the winter and until the end of May. There was sufficient green forage during the pod trial in June to meet their protein requirement. Cows had free access to a trace mineral salt block and water at all times.

Diets were estimated by a bite-count technique (Lehner 1987). Each cow was observed for 4 to 8,5 -min periods during the day whenever the cows were grazing. The number of bites of each forage class was recorded and the percentage of each forage class in the diet was estimated. The amount of locoweed consumed at the beginning of each trial, while there was still adequate forage, was a measure of its relative palatability at that growth stage. Days of the trial represented increasing grazing pressure resulting from the diminishing forage supply. An increase in locoweed consumption as the trial progressed would indicate that grazing pressure forced the cows to select white locoweed.

Each cow was considered an experimental unit because the increasing grazing pressure would be applied to each animal. The percentage of each forage class in the diets was compared between trials and over days of the trials by analysis of variance (ANOVA) in a split-plot design. Trial was the main plot and was tested by the trial-by-animal interaction. Day was the split-plot, and along with the trial-by-day interaction, was tested by the residual error. There were significant trial-by-day interactions in all forage classes $(P<.01)$, so the model was reduced and trials were analyzed separately comparing diets over days of the trial and among cows. Percentage data of forage classes in the diet were transformed by arcsin transformation, but non-transformed means are presented in the tables. Where differences occurred $(P<.05)$, means were separated by least significant difference (LSD).

Simple linear regression was used to describe the influence of grazing pressure on locoweed consumption. Grazing pressure is the ratio of forage demand to forage supply at a given time. Forage supply on each of the 10 days in the trials was extrapolated linearly from the total standing crop at the beginning and end of each trial. Forage demand was assumed to be $9 \mathrm{~kg}$ DM/cow/day and grazing pressure was calculated for each day of the trial. Regressions were calculated between locoweed consumption as the dependent variable and grazing pressure ratio as the independent variable, for the entire study, and for the 3 trials separately. There was also a difference in locoweed consumption among cows in all 3 trials. Two cows preferred locoweed and consumed it for a majority of their diets in Trials 1 and 2, and were labeled "loco-eaters", as opposed to "hormal" cows. Regressions were also calculated with all the cows

Table 1. Standing crop (kg/ha \pm standard error), pasture size (ha), and grazing pressure ratio on total standing crop at the beginning and end of each trial.

\begin{tabular}{|c|c|c|c|c|c|c|}
\hline \multirow{2}{*}{$\begin{array}{l}\text { Forage } \\
\text { Class }\end{array}$} & \multicolumn{2}{|c|}{$\begin{array}{c}\text { Trial 1, April } \\
\text { Vegetative }\end{array}$} & \multicolumn{2}{|c|}{$\begin{array}{l}\text { Trial 2, May } \\
\text { Flower }\end{array}$} & \multicolumn{2}{|c|}{$\begin{array}{l}\text { Trial 3, June } \\
\text { Pod }\end{array}$} \\
\hline & Begin & End & Begin & End & Begin & End \\
\hline Standing crop & \multicolumn{6}{|c|}{ - } \\
\hline $\begin{array}{l}\text { Cool-season grass } \\
\text { Warm-season grass } \\
\text { Forb } \\
\text { Locoweed leaf } \\
\text { Locoweed head } \\
\text { TOTAL }\end{array}$ & $\begin{array}{c}131 \pm 20 \\
449 \pm 53 \\
236 \pm 34 \\
284 \pm 58 \\
- \\
1150 \pm 73\end{array}$ & $\begin{array}{c}48 \pm 17 \\
358 \pm 42 \\
230 \pm 38 \\
98 \pm 28 \\
- \\
734 \pm 62\end{array}$ & $\begin{array}{c}208 \pm 36 \\
558 \pm 46 \\
298 \pm 38 \\
382 \pm 67 \\
162 \pm 31 \\
1608 \pm 116\end{array}$ & $\begin{array}{c}56 \pm 29 \\
378 \pm 35 \\
182 \pm 26 \\
242 \pm 60 \\
0 \\
858 \pm 71\end{array}$ & $\begin{array}{c}120 \pm 24 \\
404 \pm 27 \\
386 \pm 37 \\
404+75 \\
236+57 \\
1550 \pm 136\end{array}$ & $\begin{array}{c}96 \pm 27 \\
380 \pm 26 \\
256 \pm 27 \\
302 \pm 75 \\
108 \pm 34 \\
1142 \pm 105\end{array}$ \\
\hline $\begin{array}{l}\text { Pasture size } \\
\text { Grazing pressure ratio* }\end{array}$ & \multicolumn{2}{|c|}{1.1 ha } & \multicolumn{2}{|c|}{$1.7 \mathrm{ha}$} & \multicolumn{2}{|c|}{ 1.7ha } \\
\hline
\end{tabular}

kgDM/cow/day. 
included, and with the loco-eaters excluded from the data sets.

\section{Results}

Cattle consumed more white locoweed in Trial 2 (flower stage in May) than in the other trials (Table 2). The least amount of locoweed was consumed in Trial 3 (pod stage in June). There were differences among cows (Table 2) in each trial $(P<0.01)$. Cow 54 consumed more locoweed in all 3 trials than other cows. Cow 25 also consumed more locoweed than the remaining 5 cows in Trial 2. These 2 cows were classified as "loco-eaters". Locoweed consumption by the locoeater and "normal" groups are illustrated in Figure 1 for the 3 grazing trials.

\section{Trial 1, Vegetative Stage}

Three of 4 cows rejected locoweed during the first half of the trial (Figure 1a). Cow 54 selected locoweed for about half of her diet throughout the trial. On days 7 and 8 , the normal cows started eating

\section{LOCOWEED IN DIETS}
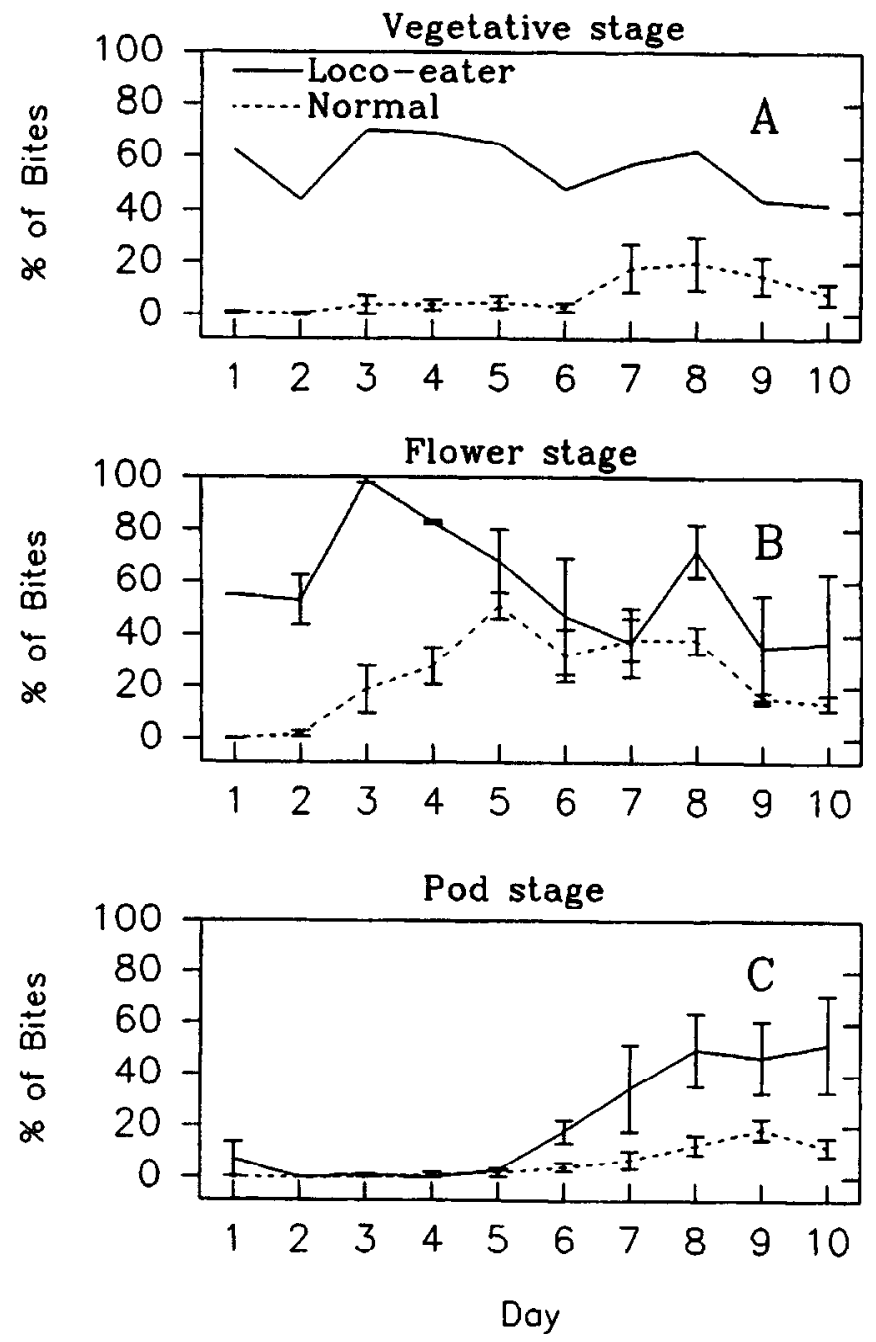

Fig 1. White locoweed in cattle diets: a) Trial 1, vegetative growth stage with one loco-eater and 3 normal cows; b) Trial 2, flower growth stage with 2 loco-eaters and 5 normal cows; and c) Trial 3, pod stage with same groups as Trial 2. Error bars are standard errors. locoweed as availability of cool-season grass decreased. The cows also increased consumption of dry, dormant warm-season grasses as availability of cool-season grasses decreased (Fig. 2a).

\section{Trial 2, Flower Stage}

The 2 loco-eaters preferred white locoweed at the beginning of the trial and consumed it for a majority of their diets throughout the trial (Fig. 1b). The normal cows rejected locoweed for the first 2 days of the trial but increased consumption of locoweed on days 3 to 5 as availability of cool-season grasses and forbs decreased. All the locoweed flowering heads had been grazed by day 6 , indicating that they were the preferred plant part. All the locoweed plants had been grazed by day 8 , and locoweed consumption declined thereafter (Fig. 1b). We observed that cattle preferred cool-season grasses that were actively growing at the beginning of the trial, but as their availability and subsequent consumption decreased, cattle switched to green locoweed and then to the dormant warm-season grasses (Fig. $2 \mathrm{~b}$ ).

\section{FORAGE CLASSES IN DIET}
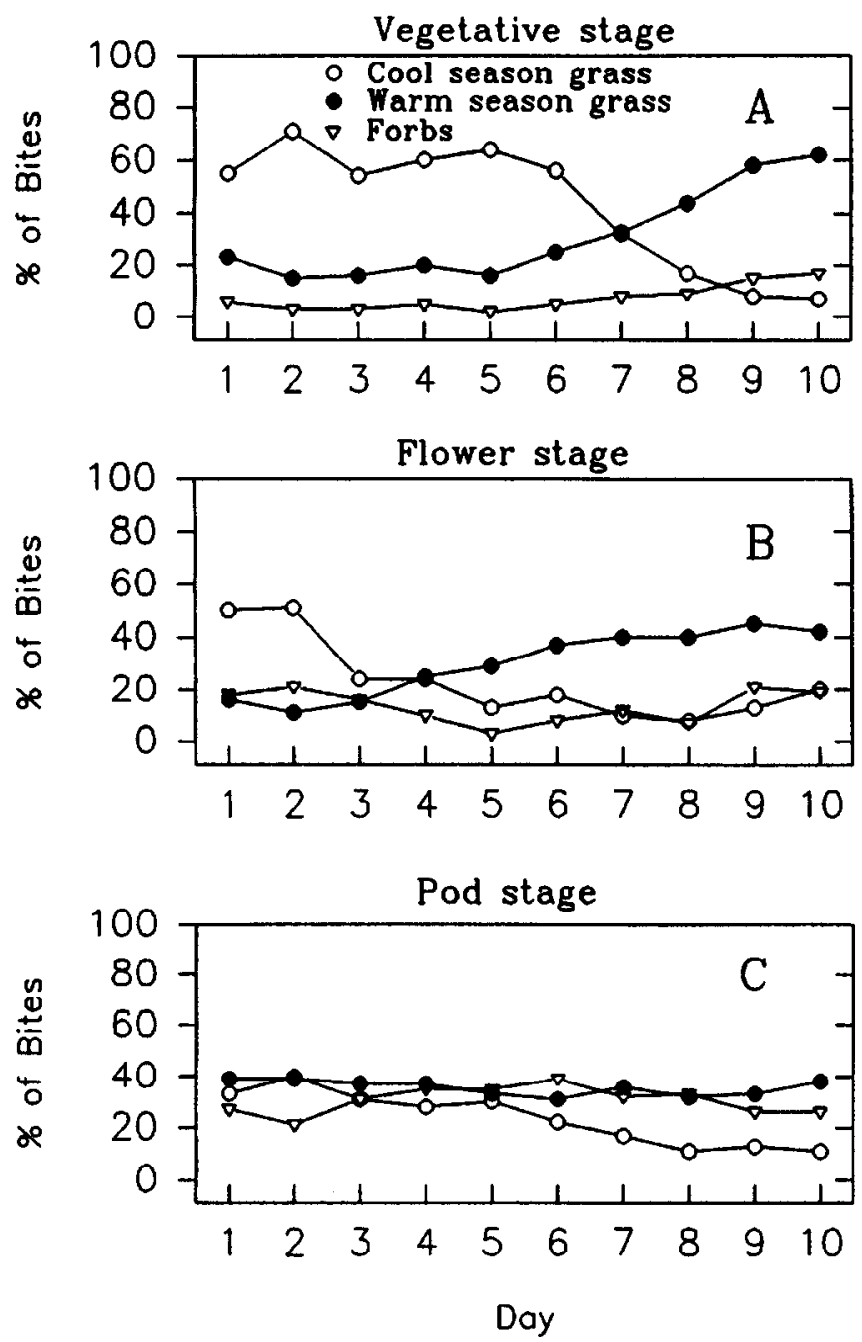

Fig 2. Forage classes in cattle diets: a) Trial 1, vegetative growth stage; b) Trial 2, flower growth stage; and c) Trial 3, pod stage. 
Table 2. Percentage of bites of white locoweed in diets of individual cows during 3 grazing trials, and the overall mean for the 3 trials.

\begin{tabular}{lcccc}
\hline Cow & $\begin{array}{c}\text { Trial 1 } \\
\text { Vegetative }\end{array}$ & $\begin{array}{c}\text { Trial 2 } \\
\text { Flower }\end{array}$ & $\begin{array}{c}\text { Trial 3 } \\
\text { Pod }\end{array}$ & Mean \\
\hline 54 & $54 \mathrm{a}$ & $69 \mathrm{a}$ & $30 \mathrm{a}$ & 51 \\
25 & - & $50 \mathrm{~b}$ & $17 \mathrm{~b}$ & 32 \\
78 & - & $29 \mathrm{c}$ & $14 \mathrm{bc}$ & 21 \\
53 & $15 \mathrm{~b}$ & $31 \mathrm{c}$ & $5 \mathrm{bc}$ & 16 \\
57 & $11 \mathrm{~b}$ & $27 \mathrm{c}$ & $6 \mathrm{bc}$ & 14 \\
79 & - & $18 \mathrm{c}$ & $4 \mathrm{c}$ & 11 \\
56 & $0 \mathrm{c}$ & $16 \mathrm{c}$ & $3 \mathrm{c}$ & 6 \\
Mean & $20 \mathrm{e}$ & $34 \mathrm{~d}$ & $10 \mathrm{f}$ & 21 \\
\hline "Means of individual cows in the same column followed by different letters are sig- \\
nificantly different $P \leq 05)$. \\
¿Means of trials in the same row followed by different letters are significantly differ- \\
ent (PS.05).
\end{tabular}

\section{Trial 3, Pod Stage}

Locoweed was not consumed by any cows at the beginning of this trial (Fig. 1c). The cows started grazing locoweed on day 6 and increased consumption as the trial progressed. Loco-eaters consumed more locoweed than the rest of the group at the end of the trial. Locoweed leaves and pods were still abundant at the end of the trial, in contrast to the 2 previous trials (Table 1). Warm-season grasses were growing rapidly during this period. and cool-season grasses. warm-season grasses, and forbs were consumed equally (Fig. 2c).

\section{Relationship Between Grazing Pressure and Locoweed Consumption}

There was a weak association between grazing pressure and locoweed consumption when all 3 trials and all animals were analyzed together (Table 3). Grazing pressure differed among trials so each trial was analyzed separately. There were also differences among cows as described above, leading to the loco-eater and normal group designation.

In Trial 1 (vegetative stage), there was no relationship between grazing pressure and locoweed consumption when all cows were included in the analysis (Table 3). This resulted from 1 cow consuming locoweed for the majority of her diet throughout the trial. When this cow was removed from the analysis, there was a significant regression indicating a moderate relationship between grazing pressure and locoweed consumption by normal cows $\left(r^{2}=0.46\right)$.

In Trial 2 (flower stage), there was no relationship between grazing pressure and locoweed consumption when all cows were included in the analysis, or when the loco-eaters were excluded. Locoweed dominated the 2 loco-eater diets at the beginning of the trial. The normal cows increased consumption as the trial progressed, but both groups decreased locoweed consumption during the last 2 days of the trial. All the flowers had been eaten and all of the locoweed plants had been grazed. Even though some locoweed leaves remained at the end of the trial (Table 1), locoweed had been grazed closely and cattle were searching for other feed. If the last 2 days (when locoweed availability was limited) are excluded from the analysis, there was a significant relationship between grazing pressure and locoweed consumption in the normal cows $\left(r^{2}=0.56\right)$.

There was a strong relationship between grazing pressure and locoweed consumption in Trial 3 (pod stage) $\left(r^{2}=0.83\right.$ to 0.88 ). Grazing pressure did not increase as much during this trial (Table 1) because rapid grass growth offset some of the forage consumption. Still, there was enough increase in grazing pressure to shift consumption patterns to white locoweed by the end of the trial.
Table 3. Relationship between grazing pressure and locoweed consumption

\begin{tabular}{|c|c|c|c|c|}
\hline Trial & Animals & $\begin{array}{l}\text { Coefficient of } \\
\text { determination }\end{array}$ & Probability & $\begin{array}{l}\text { Regression' } \\
\text { equation }\end{array}$ \\
\hline & & $r^{2}$ & $\mathrm{P}$ & \\
\hline All & All & 0.15 & 0.03 & $y=2.3+651 x$ \\
\hline Vegetative & $\begin{array}{l}\text { All } \\
\text { Without }\end{array}$ & 0.04 & 0.55 & $y=10+244 x$ \\
\hline Flower & $\begin{array}{l}\text { loco-eaters } \\
\text { All }\end{array}$ & $\begin{array}{l}0.46 \\
0.004\end{array}$ & $\begin{array}{l}0.03 \\
0.85\end{array}$ & $\begin{array}{l}y=0.22+853 x \\
y=37+140 x\end{array}$ \\
\hline & $\begin{array}{l}\text { Without } \\
\text { loco-eaters } \\
\text { Without } \\
\text { last } 2 \text { days }\end{array}$ & $\begin{array}{l}0.03 \\
0.56\end{array}$ & $\begin{array}{l}0.58 \\
0.03\end{array}$ & $\begin{array}{l}y=8+487 x \\
y=58+264 x\end{array}$ \\
\hline Pod & $\begin{array}{l}\text { All } \\
\text { Without } \\
\text { loco-eaters }\end{array}$ & $\begin{array}{ll} & 0.88 \\
& \\
\text { rs } & 0.83\end{array}$ & $\begin{array}{l}0.0001 \\
0.0003\end{array}$ & $\begin{array}{l}y=0.95+3832 x \\
y=-0.55+2205 x\end{array}$ \\
\hline
\end{tabular}

\section{Discussion and Recommendations}

Two cows preferentially selected white locoweed at the beginning of the vegetative and flower grazing trials, while other forage was still abundant. Ralphs et al. (1993) verified the classification of locoeaters and reported that loco-eaters consumed more white locoweed during April and May than non-eaters. Management options to prevent poisoning from preferred palatable poisonous plants are limited. Animals must be denied access to the plants either by controlling the plant, or removing the animal from the infested area. It is a common practice on locoweed ranges for ranchers to closely observe their cattle and remove those that start grazing locoweed.

The majority of the cows did not accept locoweed at the beginning of the grazing trials when other green forage was adequate. For these cows, white locoweed was apparently not palatable. As the 10-day trials progressed and other forage became limiting, normal cows increased consumption of white locoweed. There were significant regressions with moderate to strong relationships $\left(r^{2}=0.46\right.$ to 0.88$)$ between grazing pressure and locoweed consumption among these normal cows when availability of white locoweed was not limited.

An alternative explanation for increasing white locoweed consumption by normal cows as the trials progressed might have been their lack of immediate familiarity with white locoweed. The cows were kept in a locoweed-free pasture between grazing trials to prevent those that were eating it from becoming severely intoxicated. Since they did not have access to locoweed immediately before the trials, it may have taken them a few days to accept it. We discount this theory for 3 reasons. First, all the cows were familiar with white locoweed; they had all grazed on white locoweed-infested ranges much of their lives, and had either grazed locoweed in the previous study or had been observed grazing locoweed by the rancher. Second, the loco-eaters showed a distinct preference for white locoweed and began consuming it immediately, indicating that they required no adjustment period. Third, we also observed that the normal cows in the vegetative and flower trials preferred and sought out the green, growing cool-season grasses at the beginning of the trials. As availability of cool-season grasses decreased, the cows started to consume white locoweed. Therefore, we believe that increasing grazing pressure on the diminishing forage, especially on green grass, influenced the normal cows to increase consumption of white locoweed. 
Other studies have also reported that grazing pressure influenced cattle to graze locoweed. Ralphs et al. (1993) reported that woolly locoweed (Astragalus mollissimus var mollissimus Torr.) was not initially accepted by cattle in the spring, but grazing pressure forced them to start consuming it. On high mountain summer rangelands where green grass was abundant, grazing pressure forced cattle to start consuming white locoweed in the flower stage (Ralphs 1987).

Based upon observations from this and other studies, it appears that diminishing forage availability and the accompanying increase in grazing pressure will influence normal cattle to graze locoweed. We suggest that light or moderate stocking rates would ensure adequate forage is available, especially green forage, which will decrease the risk of forcing cattle to graze locoweed.

All the cows in this experiment, even the loco-eaters, were reluctant to eat white locoweed at the beginning of the June grazing trial when green grass was abundant and rapidly growing. Ralphs et al. (1993) also reported that cattle ceased grazing both white and woolly locoweed in June when warm-season grasses began rapid growth. This agrees with other research that suggests that locweed is not addictive (Ralphs et al. 1990, 1991). Locoweed is generally not a problem during the summer because green grass is usually abundnat and relatively more palatable than locoweed. However, heavy stocky rates on locoweed-infested rangelands during the summer will increase grazing pressure and may influence cattle to eat locoweed and become poisoned.

\section{Literature Cited}

James, L.F., K.L. Band, K.G. Parker, R.F. Keeler, W. Binns, and B. Lindsay. 1968. Loco plant poisoning in sheep. J. Range Manage. 21:360365.

James, L.F., K.R. Van Kampen, and G.R. Staker. 1969. Locoweed (Astragalus lentiginosus) poisoning in cattle and horses. J. Amer. Vet. Med. Assoc. 155: 525-530.

Lehner, P.N. 1987. Design and execution of animal behavior research: an overview. J. Anim. Sci. 65:1213-1219.

Marsh, C.D. 1909. The loco-weed disease of the plains. USDA Bureau of Animal Industry. Bull:112.

Patterson, P.E. 1982. Loco, la yerba mala. Rangelands. 4:147-148.

Peters, A.T., and L.B. Sturdevant. 1908. Locoweed poisoning in horses. Nebraska Agr. Exp. Sta. Ann. Rep. 21:75-107.

Ralphs, M.H., D. Graham, R.J. Molyneux, and L.F. James. 1993. Cattle grazing locoweed in northeastern New Mexico. J. Range Manage. 46:416420.

Ralphs, M.H., K.E. Panter and L.F. James. 1990. Feed preferences and habituation of sheep poisoned by locoweed. J. Anim. Sci. 68:1354-1362.

Ralphs, M.H., K.E. Panter, and L.F. James. 1991. Grazing behavior and forage preference of sheep with chronic locoweed toxicosis suggests no addiction. J. Range Manage. 44:208-209.

Ralphs, M.H. 1987. Cattle grazing white locoweed: influence of grazing pressure and palatability associated with phenological growth stage. J. Range Manage. 40:330-332.

Welsh, S.L. 1989. Astragalus and Oxytropis: definitions, distributions, and ecological parameters. pp. 3-13 In L.F. James, A.D. Elbein, R.J. Molyneux and C.D. Warren (eds). Swainsonine and Related Glycosidase Inhibitors. Iowa State Univ. Press, Ames. 